\title{
Spatial distribution of epiphytic chironomid larvae in a shallow macrophyte-dominated lake: effect of macrophyte species and food resources
}

\author{
Monika Tarkowska-Kukuryk
}

Received: 19 February 2013/Accepted: 9 January 2014/Published online: 7 February 2014

(C) The Author(s) 2014. This article is published with open access at Springerlink.com

\begin{abstract}
Four submerged macrophytes were analysed with their respective assemblages of chironomid and algal taxa. Studies were made bimonthly, from January to November, in a shallow macrophyte-dominated lake. The periphytic algal community was represented by chlorophytes, diatoms and cyanobacteria; diatoms showed the highest relative abundance on the macrophyte species during the study. Algal biomass was affected by the season, and in January the highest values were found on Stratiotes aloides L., Potamogeton lucens L., Myriophyllum spicatum L.; in July on Chara aculeolata Kütz. The lowest algal biomass, on most of the macrophytes studied, was found in September. Larvae of Dicrotendipes sp., Diplocladius cultriger Kieffer, Endochironomus albipennis gr., Endochironomus impar (Walker), Glyptotendipes sp. and Paratanytarsus austriacus Kieffer were dominant within the chironomid community. The spatial distribution of chironomids between macrophytes species was related to periphytic algae biomass and certain environmental variables (temperature, water transparency, biomass of chlorophytes and diatoms). Analysis of chironomid diet and the results of canonical correspondence analysis confirmed this relationship. The strongest chironomid-algae relationships were observed on S. aloides and P. lucens.
\end{abstract}

Keywords Chironomids - Submerged macrophytes · Periphytic algae $\cdot$ Trophic interactions

Handling Editor: Hong-Zhu Wang.

M. Tarkowska-Kukuryk ( $₫)$

Department of Hydrobiology, University of Life Sciences,

Dobrzańskiego 37, 20-262 Lublin, Poland

e-mail: monika.kukuryk@up.lublin.pl

\section{Introduction}

In lakes whose water is clear, species and morphological diversity of submerged macrophytes may affect the distribution and structure of epiphytic invertebrates. Macrophytes exhibit variations in structural architecture and determine the habitat area available for colonisation by invertebrates (Cyr and Downing 1988; van de Meutter et al. 2008). Plants with dissected leaves (such as Ceratophyllum demersum, Myriophyllum spicatum) are often more complex, owing to the high ratio of surface area to plant mass; thus it has been suggested this complexity increases the number of microhabitats and overall niche space for associated invertebrates (Warfe and Barmuta 2004; Hansen et al. 2011). The distribution of invertebrates between macrophyte species is also related to potential food resources (periphytic algae). Many groups of invertebrate grazers use periphytic algae as a major food resource; one of the most important is chironomid larvae (Peets et al. 1994; Balci and Kennedy 2003; Tarkowska-Kukuryk 2011). Although the larvae are able to ingest a variety of food types, including algae, detritus and associated microorganisms and macrophytes (Pinder 1986; Hirabayashi and Wotton 1999), commonly reported food items are periphytic algae (Lawrence and Gresens 2004; Tall et al. 2006; Maasri et al. 2010).

High chironomid grazing pressure may substantially reduce the biomass of periphytic algae (Jones and Sayer 2003; Tarkowska-Kukuryk 2013). For this reason, chironomid larvae may act as an important top-down regulator of periphyton biomass, and the removal of periphyton by grazing larvae may improve light conditions for macrophytes. Periphytic algae may attenuate most of the light reaching the adaxial leaf surface, and decrease the production of macrophyte species markedly (up to 60-80\%). 
Thus, periphyton is an important competitor of macrophytes for light, carbon and nutrients, and may negatively affect the growth of the hosting macrophyte (Vermaat and Hootsmans 1994; Liboriussen et al. 2005). Accumulation of periphytic algae is usually greater on thick and finely branched submerged plants such as Myriophyllum or Ranunculus than on large-leaved pondweeds (Potamogeton) (Blindow 1987; Laugaste and Reunanen 2005). Understanding the algae-chironomid relationship of different macrophyte species requires an analysis of chironomid diet.

The colonisation of macrophyte species by periphytic algae and chironomids may also be stimulated by fish. Intensive fish foraging may substantially reduce the number of grazers (Brönmark et al. 1992; McCollum et al. 1988). The refuge effect of macrophytes is particularly evident in clear-water lakes, and depends on the macrophyte species. Koperski (1998) and Rantala et al. (2004) have stressed the role of the macrophyte species Stratiotes aloides as an effective shelter against predator pressure; similarly, dense characean stands may prevent intensive fish foraging (James et al. 2000). These highly developed green algae tend to cover the sediment in dense mats which resemble meadows.

To date a number of field and laboratory studies have focused on the relationships between plant morphology (substrate surface, habitat complexity) and associated invertebrates (Lalonde and Dowing 1991; Taniguchi et al. 2003; Tessier et al. 2004; Becerra-Munoz and Schramm 2007; Hansen et al. 2011). Only a few considered the structure and biomass of periphytic algae as a factor potentially determining the selection of macrophyte species by invertebrates (Dvorak 1996; Cattaneo et al. 1998). The significant contribution of environmental variables on chironomid variability is already known. Brooks et al. (2001) showed that chironomid assemblages in lakes of the north-west of England are structured by total phosphorus (TP), dissolved oxygen, lake depth, Secchi disc transparency and water temperature; in polluted water-bodies, the most important variables are dissolved oxygen and food availability (Lindegaard 1995). The chironomids associated with the common reed (Phragmites australis (Cav.) Trin. ex Steud.) are mostly affected by nutrients, epiphytic chlorophyll- $a$, periphyton biomass, reed density and total organic carbon (Cañedo-Argüelles and Rieradevall 2009; Tarkowska-Kukuryk 2011). Nevertheless, the determinants governing spatial distribution of chironomid species between macrophytes in clear-water lakes are still not well recognised.

During the study the following hypotheses were tested: that in a macrophyte-dominated lake: (1) the morphological structure of macrophytes determines the colonisation area and availability of food resources (periphytic algae) for chironomids; (2) the distribution of chironomids between macrophyte species is affected by the macrophyte species and the composition of periphytic algae; and (3) the relationships between macrophytes and associated chironomid larvae are affected by environmental variables (water temperature, Secchi disc transparency, oxygen content, nutrients).

The general objectives of the study were as follows: (1) to describe the taxonomic composition and abundance of periphytic algae and of chironomid larvae on four macrophyte species with different morphological structures; (2) to identify algal taxa in the guts of the dominant chironomid taxa and to compare them with the composition of the periphytic algae; and (3) to determine the environmental (habitat) conditions affecting the distribution of chironomids between macrophyte species.

\section{Methods}

\section{Lake Skomielno}

Lake Skomielno is a shallow, macrophyte-dominated lake situated in Polesie Lubelskie (eastern Poland) $\left(51^{\circ} 29^{\prime} \mathrm{N}\right.$, $23^{\circ} 0^{\prime} \mathrm{E}$, max. depth $6.5 \mathrm{~m}$, surface area $75 \mathrm{ha}$ ). The lake is slightly eutrophic; the water is well oxygenated and transparent. Secchi disc transparency often reached the bottom, except in the deepest part of the lake. The bottom area overgrown by vegetation exceeded $67 \%$.

The study sites were situated inside beds of Chara aculeolata (site 1; north-eastern part of the lake; sampling depth $1.5 \mathrm{~m}$ ), Stratiotes aloides (site 2; southern part of the lake; sampling depth $0.9 \mathrm{~m}$ ), Potamogeton lucens (site 3; south-western part of the lake; sampling depth $1.2 \mathrm{~m}$ ) and Myriophyllum spicatum (site 4; south-eastern part of the lake; depth $0.8 \mathrm{~m}$ ). Samples of macrophytes, periphytic algae and chironomids were collected simultaneously, bimonthly from January to November during 2008 and 2009 , assuming that every month is a season. Three replicates were collected each sampling month and from each site.

Macrophyte structure and samplings

The four macrophyte species (Chara aculeolata, Stratiotes aloides, Potamogeton lucens and Myriophyllum spicatum) chosen for the analysis of spatial distribution of larval chironomid differ in their morphological structure, and are expected to show differences in colonisation area and potential food source (periphytic algae) for chironomids.

Hedgehog stonewort (Ch. aculeolata) is a highly developed green alga; in the studied lake it forms dense mats covering the sediments. Water soldier (S. aloides) is a 
vascular plant species forming large rosettes which float on the water surface from late spring to autumn. Shining pondweed ( $P$. lucens) forms long, rooted stems with lanceolate leaves; the plants grow up to the water surface. Eurasian watermilfoil (M. spicatum) is a perennial plant species that forms short, branched shoots with finely dissected leaves.

For the evaluation of the biomass of macrophyte species (g wet weight $(\mathrm{WW}) \mathrm{m}^{-2}$ ), the plants were harvested using a Bernatowicz rake (surface area $0.16 \mathrm{~m}^{2}$ ) (Bernatowicz 1960); at each sampling date and site three replicates were taken. Each macrophyte sample was put into a separate plastic bag. At the laboratory the plants were washed gently under running tap water to avoid tissue damage, blotted out to remove the surface moisture, and weighed to obtain the WW. Each sample was washed and weighed separately.

\section{Periphytic algae sampling}

A sample was taken by cutting off a plant fragment (ensuring the length was the same for all macrophyte species) in a water column, and putting it into a plastic bag. The content of each bag was transferred into a plastic bottle filled with $300 \mathrm{ml}$ of distilled water. Epiphytic algae were separated from the plant by shaking the sealed bottle vigorously for $2 \mathrm{~min}$. The suspension was filtered through a $300-\mu \mathrm{m}$ mesh size to avoid contamination by small plant fragments or occasional invertebrates. From this sample, a 100-ml algal sample was fixed with Lugols solution and then with a formaldehyde-glycerin solution. A 2-ml aliquot was taken from the subsample and put in a 10-ml Utermöhl counting chamber and then filled with filtered water (GF/C filter). After settling, at least 200 algal cells were counted along one or more grid lines. All cells of colonial algae were counted; each filament with a length of $100 \mu \mathrm{m}$ was counted as one cell. Counting and identification were performed at $400 \times$ magnification under an inverted microscope equipped with a calibration micrometer. Identification to genus level was based on the keys of van den Hoek et al. (1995). The biomass of the periphytic algae was calculated using the lengths and widths of algal cells and common geometric equations (Rott 1981), and expressed in micrograms per $100 \mathrm{~g}$ of dry weight (DW) of plant. The plant fragments collected for the analysis were dried at $105{ }^{\circ} \mathrm{C}$ for $24 \mathrm{~h}$ and then weighed to obtain the DW. The relative abundance of algal taxonomic groups was estimated in the total biomass of algae, based on the biomass of counted cells and filaments.

\section{Chironomid sampling}

Chironomid larvae were collected from the periphyton using a perspex cylindrical apparatus (wall thickness $0.5 \mathrm{~cm}$, length $32 \mathrm{~cm}$, diameter $13 \mathrm{~cm}$, weight $800 \mathrm{~g}$ ), with openings covered by $250-\mu \mathrm{m}$ mesh nets (Kornijów 1998). The open apparatus was lowered into the macrophyte bed and a plant fragment was put very gently inside the cylinder using a small floristic fork. The sampler was closed very slowly to minimise water movement and raised in a horizontal position to the surface. The shoots protruding beyond the top of the sampler were cut off. The water from the cylinder flowed out, the sampler was opened and the plant material was transferred to a plastic bag. Next, the sampler was put in a vertical position and flushed with water outside to rinse animals remaining on the net to the bottom of the cylinder where they could be collected easily. At the laboratory, the larvae were removed from the macrophyte samples, preserved in $4 \%$ formaldehyde solution, counted and identified. Chironomidae larvae nomenclature followed Chernovski (1949) and Wiederholm (1983). Density was calculated per $100 \mathrm{~g}$ DW of plant. The DW of plants collected in a single sample was estimated using the same method as for periphytic algae.

\section{Gut analysis}

At each macrophyte species sampling site and on each sampling date (month), ten larvae of each dominant taxon were selected for gut content analysis. The larvae were rinsed of any surface debris, decapitated and dissected along the length of their body and placed in Eppendorf tubes filled with filtered water (GF/C filter). Each tube stored the content of one single gut. The tubes were fixed on a shaker for $20 \mathrm{~min}$ to dislodge the gut contents from the digestive tube tissues. Next, the gut content solutions were put separately into a 10-ml counting chamber and filled with filtered water (GF/C). After settling, algae in the gut contents were identified and counted under an inverted microscope.

The relative abundance of cyanobacteria, diatoms, and chlorophytes found in the gut were assessed as a percentage ratio of the total number of cells (filaments) of each algal group to the total number of particles counted on the slide. Each filament of $100 \mu \mathrm{m}$ length was calculated as one cell.

Physical and chemical water parameters

Water samples for chemical analysis were taken bimonthly from January 2008 to November 2009, simultaneously with periphytic algae and chironomid samples. Samples were taken inside each macrophyte bed. Three replicates were collected on each sampling date and at each site. Temperature, $\mathrm{pH}$, conductivity and dissolved oxygen were recorded in situ using the YSI 556 MPS electrode. Planktonic and periphytic chlorophyll- $a$ values were determined by the spectrophotometric method following a 24-h extraction with $90 \%$ acetone in the dark (Golterman 1969). Concentrations of nutrients $\left(\mathrm{N}-\mathrm{NH}_{4}, \mathrm{~N}-\mathrm{NO}_{3}, \mathrm{TP}\right.$, 
$\mathrm{P}-\mathrm{PO}_{4}$ ) were analysed using spectrophotometric methods (Hermanowicz et al. 1999).

Data analysis

All data collected during the 2-year study was verified statistically. Data was $\log +1$ transformed to normal distribution. The statistical analysis showed a lack of significant inter-annual differences, thus the results presented in Figures and Tables are mean values for 2008-2009 for each month of collection. The influence of macrophyte species and season on the biomass of periphytic algae and spatial distribution of chironomid larvae was verified using two-way analysis of variance (ANOVA). To recognise the role of periphytic algae as a direct food source for chironomids, Pearsons correlation coefficients were calculated. The correlations were calculated on the data of chironomid abundance and algal biomass and calculations were made using all data collected during the 2-year study. For each macrophyte species site, the number of samples was $n=36$ (6 months $\times 3$ replicates $\times 2$ years). Analysis was performed using STATISTICA 7.0 Software (Statsoft Inc., 2004).

Ordination analysis was performed to specify habitat conditions responsible for chironomid distribution (abundance) between plant species. Canonical correspondence analysis (CCA) was used to explore the relationships between the abundance of chironomid taxa and environmental variables (ter Braak and Šmilauer 2002). Automatic forward selection of environmental variables (Monte Carlo permutation test) was used to determine the most important variables (Lepš and Šmilauer 2003). Variables whose level of significance exceeded 0.05 were marked passively on the diagrams. The ordination analyses were performed using CANOCO 4.5 for Windows ${ }^{\circledR}$.

\section{Results}

Physical and chemical parameters of the water

At the studied sites, the physical and chemical water parameter values were typical for slightly eutrophic, macrophyte-dominated lakes. Concentrations of planktonic chlorophyll- $a$ were low $\left(2.9-42.8 \mu \mathrm{g} \mathrm{l}^{-1}\right)$ and resulted in high Secchi disc transparency $(0.5-1.5 \mathrm{~m})$. Concentrations of nitrogen compounds were affected by season; $\mathrm{N}-\mathrm{NH}_{4}$ showed the highest values in September (0.552-0.934 $\mathrm{mg} \mathrm{l}^{-1}$ ) and $\mathrm{N}-\mathrm{NO}_{3}$ in November $\left(0.436-0.525 \mathrm{mg} \mathrm{l}^{-1}\right)$. Concentrations of TP depended on the site and reached the highest values in May, with 0.116 and $0.059 \mathrm{mg}^{-1}$ for $C h$. aculeolata and $S$. aloides, respectively; July with a value of $0.091 \mathrm{mg}^{-1}$ for $P$. lucens; and November, with a value of $0.440 \mathrm{mg}^{-1}$ for $M$. spicatum. The highest concentrations of $\mathrm{P}-\mathrm{PO}_{4}$ were noted in January $\left(0.024-0.033 \mathrm{mg} \mathrm{l}^{-1}\right)$, except for the site with $P$. lucens. At that site, the peak value of $\mathrm{P}-$ $\mathrm{PO}_{4}\left(0.043 \mathrm{mg} \mathrm{l}^{-1}\right)$ was found in July.

Structure of biomass of macrophyte species

The mean biomass of the macrophytes studied was in the range of $254.7-2,238.2 \mathrm{~g} \mathrm{WW} \mathrm{m}^{-2}$ and showed a clear variation between the months (Table 1). On individual macrophyte species, the lowest biomass (254.7-909.2

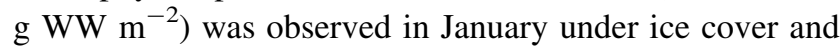
the highest (1,097.7-2,238.2 $\left.\mathrm{g} \mathrm{WW}^{-2}\right)$ mostly in July, the peak of the growing season. P. lucens showed the highest biomass $\left(1,105.6 \mathrm{~g} \mathrm{WW} \mathrm{m}^{-2}\right)$ in May.

Structure and biomass of periphytic algae

The total biomass of periphytic algae $\left(\mu \mathrm{g} 100 \mathrm{~g} \mathrm{DW}^{-1}\right)$ differed significantly between macrophyte species (ANOVA; $F=55.93 ; P<0.001$ ) and seasons (ANOVA; $F=50.56 ; P<0.001$ ) (Fig. 1). At most sites the highest

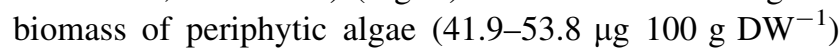
was observed under ice cover in January, and the lowest in September (4.7-7.3 $\mu \mathrm{g} 100 \mathrm{~g} \mathrm{DW}^{-1}$ ). At the Ch. aculeolata site, the highest total algal biomass was recorded in July $\left(25.4 \mu \mathrm{g} 100 \mathrm{~g} \mathrm{DW}^{-1}\right)$ and the lowest in November (14.8 $\left.\mu \mathrm{g} 100 \mathrm{~g} \mathrm{DW}^{-1}\right)$.

Three taxonomic algal groups (chlorophytes, diatoms and cyanobacteria) were observed on the studied macrophytes (Fig. 1). Diatoms were predominant in the algal biomass on Ch. aculeolata $\left(6.2-9.8 \mu \mathrm{g} 100 \mathrm{~g} \mathrm{DW}^{-1}\right)$ and

Table 1 Seasonal variability of the biomass $\left(\mathrm{g} \mathrm{WW} \mathrm{m}^{-2}\right.$ ) of four studied macrophyte species in Lake Skomielno (mean values are presented in brackets)

\begin{tabular}{|c|c|c|c|c|c|c|}
\hline & Jan & Mar & May & Jul & Sep & Nov \\
\hline $\begin{array}{l}\text { Chara } \\
\text { aculeolata }\end{array}$ & $179.8-1,218.4(607.2)$ & $256.6-1,723.4$ (982.6) & $177.1-3,650.6(1,458.2)$ & $209.0-4,225.0(1,644.1)$ & $139.6-3,490.0(1,265.1)$ & $216.4-1,352.2(811.3)$ \\
\hline $\begin{array}{c}\text { Stratiotes } \\
\text { aloides }\end{array}$ & 236.6-1,998.7 (909.2) & $307.1-1,352.8(797.8)$ & $228.04-2,224.5$ (928.9) & $743.8-4,371.5(2,238.2)$ & $555.6-3,472.5(1,723.1)$ & $108.4-1,891.5(1,657.5)$ \\
\hline $\begin{array}{l}\text { Potamogeton } \\
\text { lucens }\end{array}$ & $88.2-551.3(254.7)$ & $176.8-493.6(303.9)$ & $128.6-3,281.5(1,312.6)$ & $376.4-2,352.4(1,105.6)$ & $327.2-2,045.0(961.2)$ & $213.2-1,332.5(638.3)$ \\
\hline $\begin{array}{l}\text { Myriophyllum } \\
\text { spicatum }\end{array}$ & $323.2-794.6(392.2)$ & $89.4-941.2(546.5)$ & $435.3-2,834.3$ (997.9) & $524.2-2,272.8(1,097.7)$ & $288.8-1,974.0(895.6)$ & $354.2-1,397.8(428.7)$ \\
\hline
\end{tabular}


Fig. 1 Structure of biomass of periphytic algae on four studied macrophytes in Lake Skomielno (mean values 2008-2009 for each month of collection)

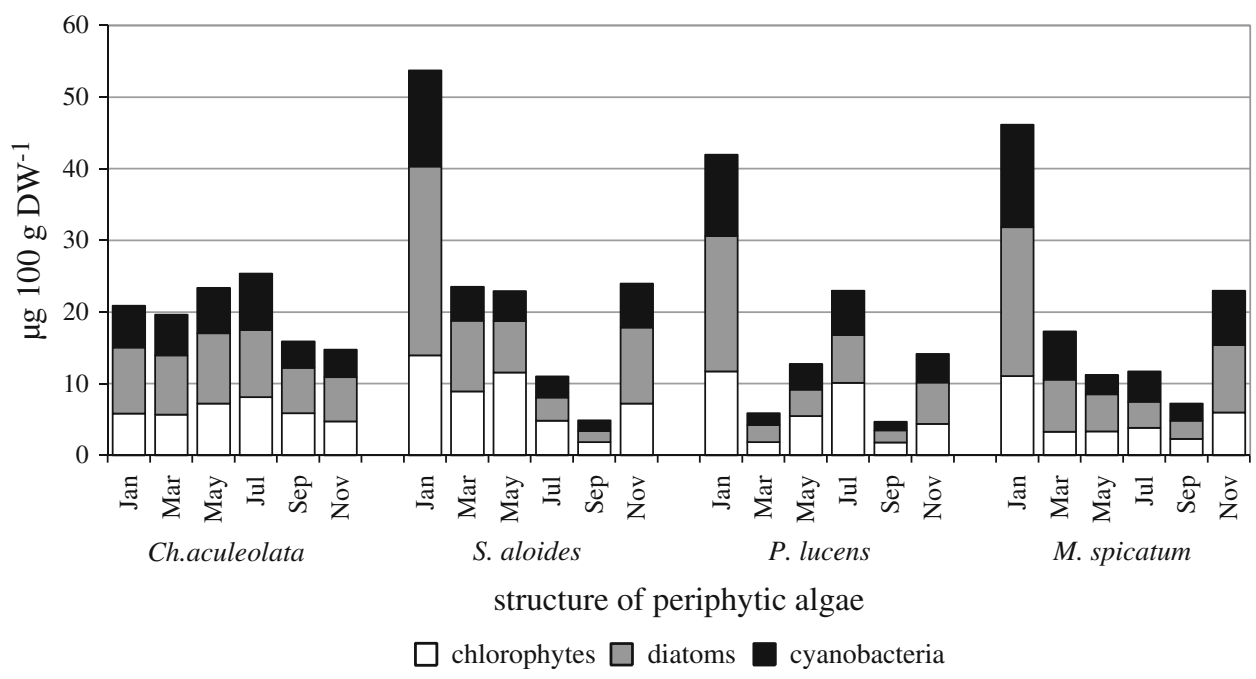

M. spicatum (2.5-20.8 $\left.\mu \mathrm{g} 100 \mathrm{~g} \mathrm{DW}^{-1}\right)$. On S. aloides and $P$. lucens, diatoms were dominant in January (26.3 and $18.8 \mu \mathrm{g} 100 \mathrm{~g} \mathrm{DW}^{-1}$, respectively); March (9.9 and $2.4 \mu \mathrm{g}$ $100 \mathrm{~g} \mathrm{DW}^{-1}$, respectively); and November (10.6 and $5.8 \mu \mathrm{g} 100 \mathrm{~g} \mathrm{DW}^{-1}$, respectively). In the remaining months, the highest biomass was noted for chlorophytes (1.9-11.6 $\mu \mathrm{g} 100 \mathrm{~g} \mathrm{DW}^{-1}$ ). Cyanobacteria showed the highest biomass in January (9.2-26.3 $\left.\mu \mathrm{g} 100 \mathrm{~g} \mathrm{DW}^{-1}\right)$ and November (5.8-10.6 $\left.\mu \mathrm{g} 100 \mathrm{~g} \mathrm{DW}^{-1}\right)$.

Density and dominance of chironomid larvae

The total density of chironomid larvae varied from 9 individuals $100 \mathrm{~g} \mathrm{DW}^{-1}$ (September, Ch. aculeolata) to 289 individuals $100 \mathrm{~g} \mathrm{DW}^{-1}$ (January, S. aloides) and was significantly affected by the season (ANOVA, $F=1.41$; $P=0.027$ ) and macrophyte species (ANOVA, $F=3.19$; $P=0.004)$ (Fig. 2). On $P$. lucens (25-202 individuals $\left.100 \mathrm{~g} \mathrm{DW}^{-1}\right)$ and $S$. aloides (17-289 individuals $100 \mathrm{~g} \mathrm{DW}^{-1}$ ) chironomids showed visibly higher abundance. The lowest densities were usually noted in summer (July, September) and the highest in winter (January, March) (Fig. 2).

In total, 18 taxa of larval chironomids were noted on the macrophyte species studied (Table 2). There were differences between macrophytes in the number of taxa as well as in their abundance. The highest number of taxa (12) was observed on S. aloides and P. lucens and the lowest (7 taxa) on Ch. aculeolata. On Ch. aculeolata, larvae of Dicrotendipes sp. (22-48 individuals $100 \mathrm{~g} \mathrm{DW}^{-1}$ ) and Paratanytarsus austriacus (11-30 individuals $\left.100 \mathrm{~g} \mathrm{DW}^{-1}\right)$ showed the highest abundance. On $S$. aloides, larvae of Diplocladius cultriger (15-92 individuals $100 \mathrm{~g} \mathrm{DW}^{-1}$ ), Dicrotendipes sp. (5-61 individuals $100 \mathrm{~g} \mathrm{DW}^{-1}$ ) and Glyptotendipes sp. were dominant, with numbers reaching from 8 to 55 individuals $100 \mathrm{~g} \mathrm{DW}^{-1}$. Larvae of
Dicrotendipes sp. (3-44 individuals $100 \mathrm{~g} \mathrm{DW}^{-1}$ ), Paratanytarsus austriacus (16-186 individuals $100 \mathrm{~g} \mathrm{DW}^{-1}$ ) and Endochironomus albipennis gr. (3-68 individuals $100 \mathrm{~g} \mathrm{DW}^{-1}$ ) were very abundant on Potamogeton lucens. On $M$. spicatum, the larvae of Psectrocladius sordidellus gr. (37-39 individuals $100 \mathrm{~g} \mathrm{DW}^{-1}$ ), Dicrotendipes sp. (5-38 individuals $100 \mathrm{~g} \mathrm{DW}^{-1}$ ) and Cricotopus sylvestris gr. were dominant, and amounted to 16-20 individuals $100 \mathrm{~g} \mathrm{DW}^{-1}$.

Periphytic algae in the diet of chironomids

The relative abundance of periphytic algae in the chironomid gut showed high variability between seasons, macrophyte and chironomid species, and varied from 30 to $90 \%$ (Fig. 3). The remainder of the chironomid diet comprised amorphous detritus. The highest relative abundance of algae was observed in the diet of Dicrotendipes sp. (40-90\%), Glyptotendipes sp. (40-85\%), Endochironomus albipennis (70-78 \%) and Endochironomus impar (70-78 \%). The larvae fed mostly on diatoms; their percentages varied between 13 and $68 \%$ of the larval diet (Fig. 3). Cyanobacteria were noted in the chironomid diet occasionally, and in low proportions (2-8\%).

Chironomids associated with $S$. aloides and Potamogeton lucens showed the highest proportion of algae in their guts (Fig. 3). Depending on the season, the relative abundance of algae in the larval diet varied from 30 to $90 \%(S$. aloides) and from 35 to $78 \%$ (P. lucens). On M. spicatum, the proportions of algae in the chironomid gut were visibly lower. The relative abundance of algae in the larval diet did not usually exceed $50 \%$.

Environmental conditions versus chironomid structure

The results of CCA for spatial distribution of chironomid larvae showed that all environmental variables accounted 
Fig. 2 Mean density $( \pm \mathrm{SE})$ of chironomid larvae associated with four submerged macrophytes in Lake Skomielno (mean values 2008-2009 for each month of collection)

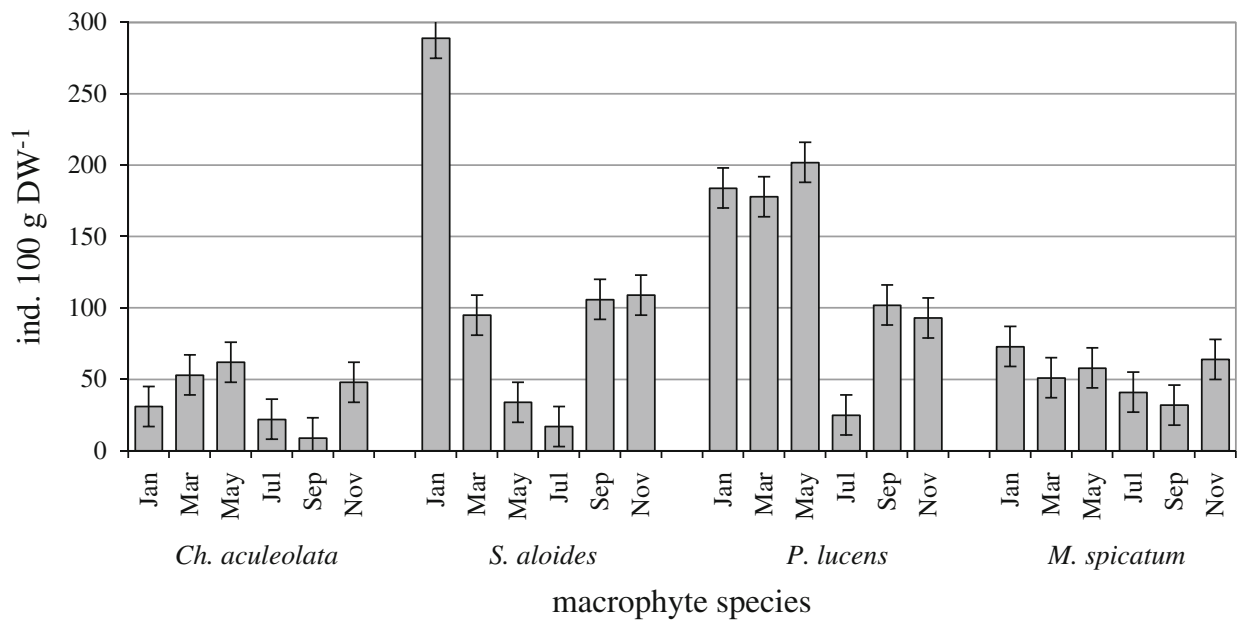

for $73.2 \%$ of the total variance of chironomid abundance. However, only four variables (the results of the Monte Carlo permutation test) showed a significant effect on the distribution of chironomid larvae between macrophyte species: temperature $(\lambda=0.52 ; F=3.50 ; P=0.002)$; Secchi disc transparency $(\lambda=0.37 ; \quad F=2.71$; $P=0.002)$; biomass of chlorophytes $(\lambda=0.34 ; F=2.86$; $P=0.004) ; \quad$ and diatoms $\quad(\lambda=0.28 ; \quad F=2.16$; $P=0.010$ ). The CCA plots (Fig. 4a,b) show the samples separated into three groups by macrophyte species: $S$. aloides (group I), P. lucens (group II), Ch. aculeolata and M. spicatum (group III). The chironomid taxa (Diplocladius cultriger, Dicrotendipes sp., Endochironomus impar, Glyptotendipes sp., Microtendipes rydalensis and Polypedilum nubeculosum gr.) collected on S. aloides correspond with a rising gradient of dissolved oxygen, $\mathrm{P}-\mathrm{PO}_{4}$ and diatom biomass. The largest group of chironomid taxa (Psectrocladius sp., Allochironomus sp., Cladotanytarsus mancus, Paratanytarsus austriacus, Endochironomus albipennis gr., Phaenopsectra flavipes, Polypedilum convictum gr., P. sordens) associated with Potamogeton lucens showed a positive relation to the rising temperature gradient, Secchi disc transparency and chlorophyte biomass. The abundance of chironomid taxa Ablabesmyia phatta, Cricotopus sylvestris gr., Psectrocladius sordidellus gr., and Cladopelma lateralis observed on Ch. aculeolata and Myriophyllum spicatum corresponded with higher concentrations of $\mathrm{N}-\mathrm{NH}_{4}, \mathrm{~N}-\mathrm{NO}_{3}$, Ptot, conductivity and cyanobacterial biomass.

Relationships between algae and chironomids

A significant relationship between algal biomass and chironomid density was noted only for the most abundant chironomid taxa (Table 3). Chironomid taxa, Diplocladius cultriger, Glyptotendipes sp., Microtendipes rydalensis gr. and Phaenopsectra flavipes showed a significant correlation with periphytic algae on $S$. aloides. The abundance of Psectrocladius sordidellus gr., Dicrotendipes sp. and Polypedilum sordens was positively related to algal biomass on Potamogeton lucens. The density of Cricotopus sylvestris gr. was positively correlated with algal biomass on Myriophyllum spicatum. A significant relationship between Paratanytarsus austriacus and algae was noted on Ch. aculeolata.

\section{Discussion}

The macrophyte species studied differ in terms of total biomass of periphytic algae, but not in the structure of the algal community. Diatoms were the dominant periphytic algae on the studied macrophytes, and such a taxonomic composition is typical for lakes with abundant soft vegetation (Pip and Robinson 1984; Gross et al. 2003). Cyanobacteria were a minor component of the periphyton community. These algae often dominate at low light availability and in nutrient-rich lakes (Loeb and Reuter 1981; Toporowska et al. 2010). Allelopathy may be another explanation of low cyanobacterial biomass on the studied plant species. Excretion of toxic substances from Chara or Myriophyllum may inhibit the growth of algae, and has been suggested as being responsible for the low density of cyanobacteria (Mulderij et al. 2007; Bauer et al. 2009). The converse results were presented in the studies of Moeller et al. (1988) and Kahlert and Pettersson (2002); these demonstrated that under low nutrient availability, the periphyton communities associated with macrophytes are highly host-specific. At the study site, Lake Skomielno, the morphology of plant species does not appear to be the main factor influencing periphyton richness. Conversely, the results of Laugaste and Reunanen (2005) showed that the submerged plants richest in periphytic algae are densely growing and have fine branchlets, such as Ranunculus 


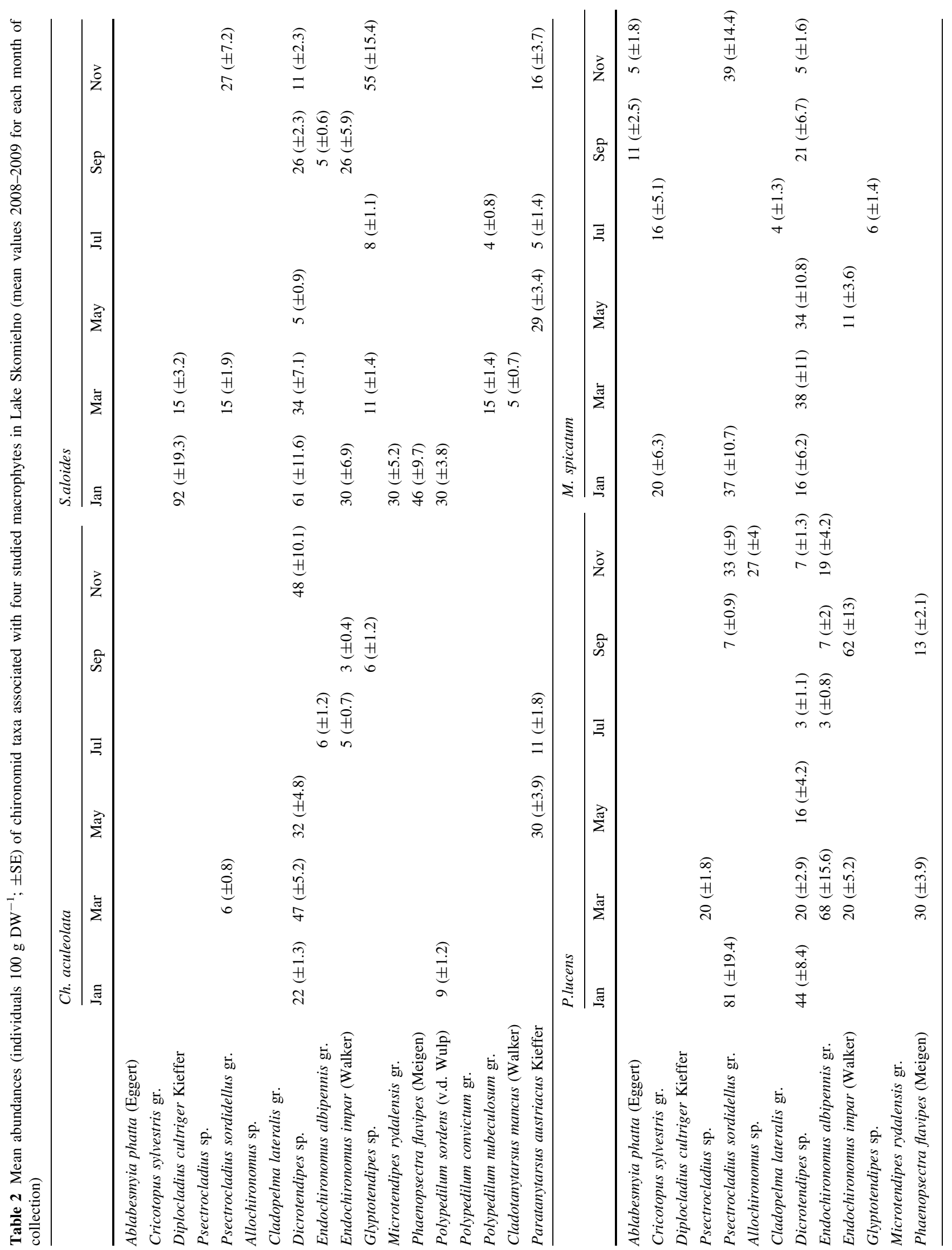




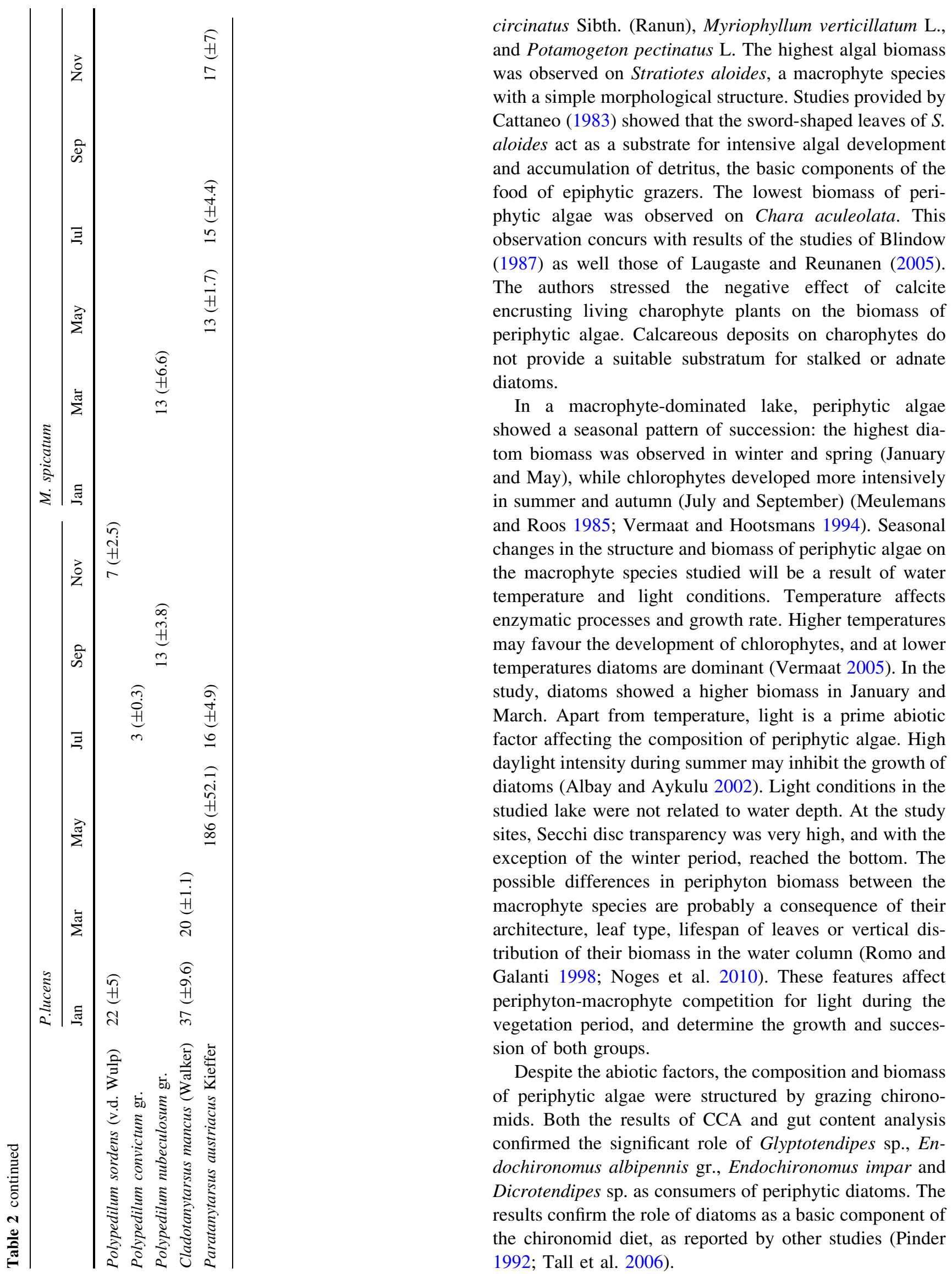




\section{(A) Chara aculeolata}

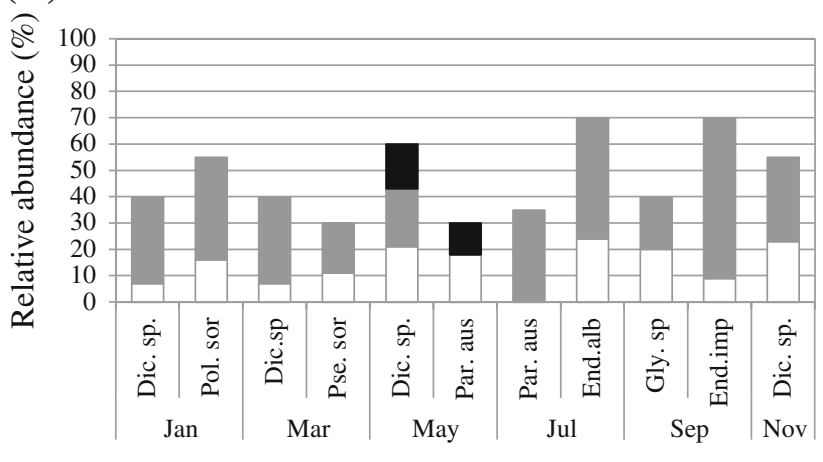

structure of chironomid diet

(C) Potamogeton lucens

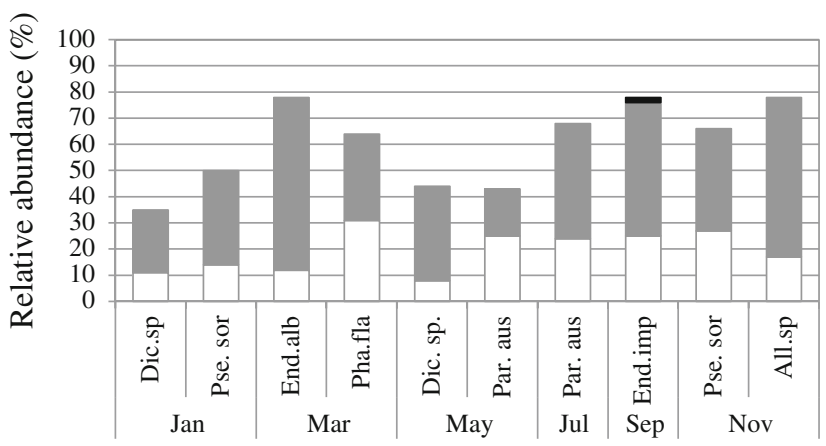

structure of chironomid diet

chlorophytes

Fig. 3 Relative abundances of periphytic algae in the guts of dominant chironomids on four macrophyte species in Lake Skomielno (mean values 2008-2009 for each month of collection). Taxa codes: Abl.pha Ablabesmyia phatta, All.sp Allochironomus sp, Cla.man Cladotanytarsus mancus, Cri.syl Cricotopus sylvestris, Dic.sp Dicrotendipes sp, Dip.cul Diplocladius cultriger, End.alb Endochironomus

In a macrophyte-dominated lake, larval chironomids showed spatial distribution between macrophyte species. In contrast to the results of studies by Dvorak and Best (1982), Cyr and Downing (1988) and Cheruvelil et al. (2000), the highest taxa richness and density of chironomids were noted on macrophytes with simple morphological structure (leaf architecture): S. aloides and P. lucens. On both macrophytes, surface dwellers and miner species were observed. The density of miner species was very low (about 10 individuals $100 \mathrm{~g} \mathrm{DW}^{-1}$ ). The mining larvae on both macrophyte species were represented mostly by larvae of Glyptotendipes sp., a commonly reported leaf-miner (Kornijów 1986; Tarkowska-Kukuryk 2006). On the leaf surface, Cricotopus sylvestris gr., Psectrocladius sordidellus gr., Dicrotendipes sp., Glyptotendipes sp., Endochironomus albipennis gr. and Paratanytarsus austriacus were dominant. These taxa are typical for eutrophic lakes
(B) Stratiotes aloides

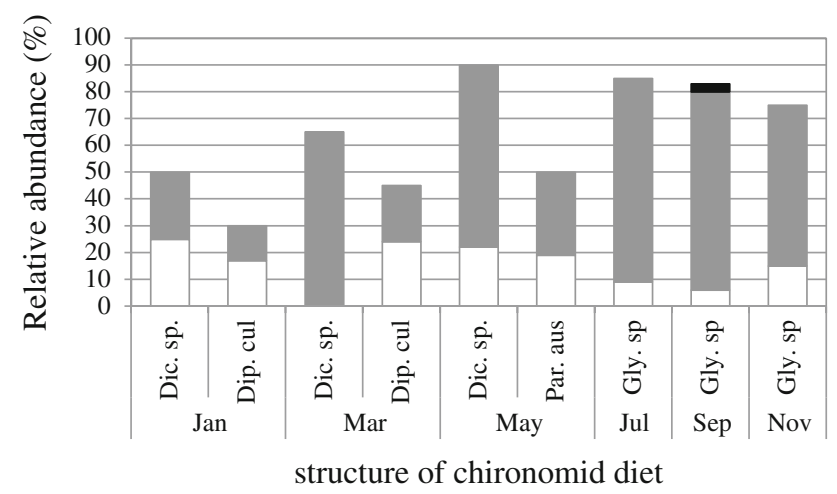

(D) Myriophyllum spicatum

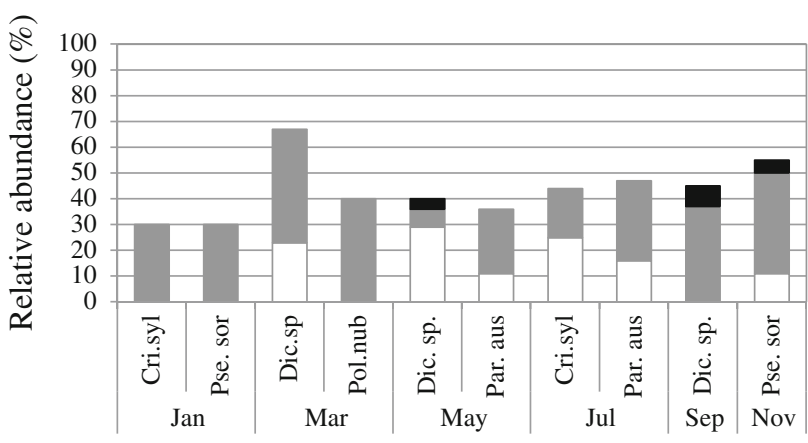

structure of chironomid diet

diatoms

cyanobacteria

albipennis, End.imp Endochironomus impar, Gly.sp Glyptotendipes sp, Par.aus Paratanytarsus austriacus, Pha.fla Phaenopsectra flavipes, Pol.con Polypedilum convictum, Pol.nub Polypedilum nubeculosum, Pol.sor Polypedilum sordens, Pse.sp Psectrocladius sp, Pse.sor Psectrocladius sordidellus

with well-developed submerged vegetation (Lods-Crozet and Lachavanne 1994; Berg 1995; Cerba et al. 2010). The highest density of chironomids was observed on S. aloides, and the highest species richness on Potamogeton lucens. The chironomid abundance on both macrophytes was positively related to the biomass of periphytic algae and may indicate the direct role of algae as food for grazing larvae. On $S$. aloides, the highest proportion of algae in the diet was observed in July and September. At that time, the total algal biomass was at its lowest, and larvae of Glyptotendipes sp. predominated among the chironomids. A similar algae-chironomid relationship was noted on $P$. $l u$ cens in March and September. In both seasons, the biomass of algae was very low while its proportion in the diet of dominant chironomids (Endochironomus albipennis gr. and Endochironomus impar) exceeded $70 \%$. The role of Glyptotendipes sp. and Endochironomus albipennis gr. as 

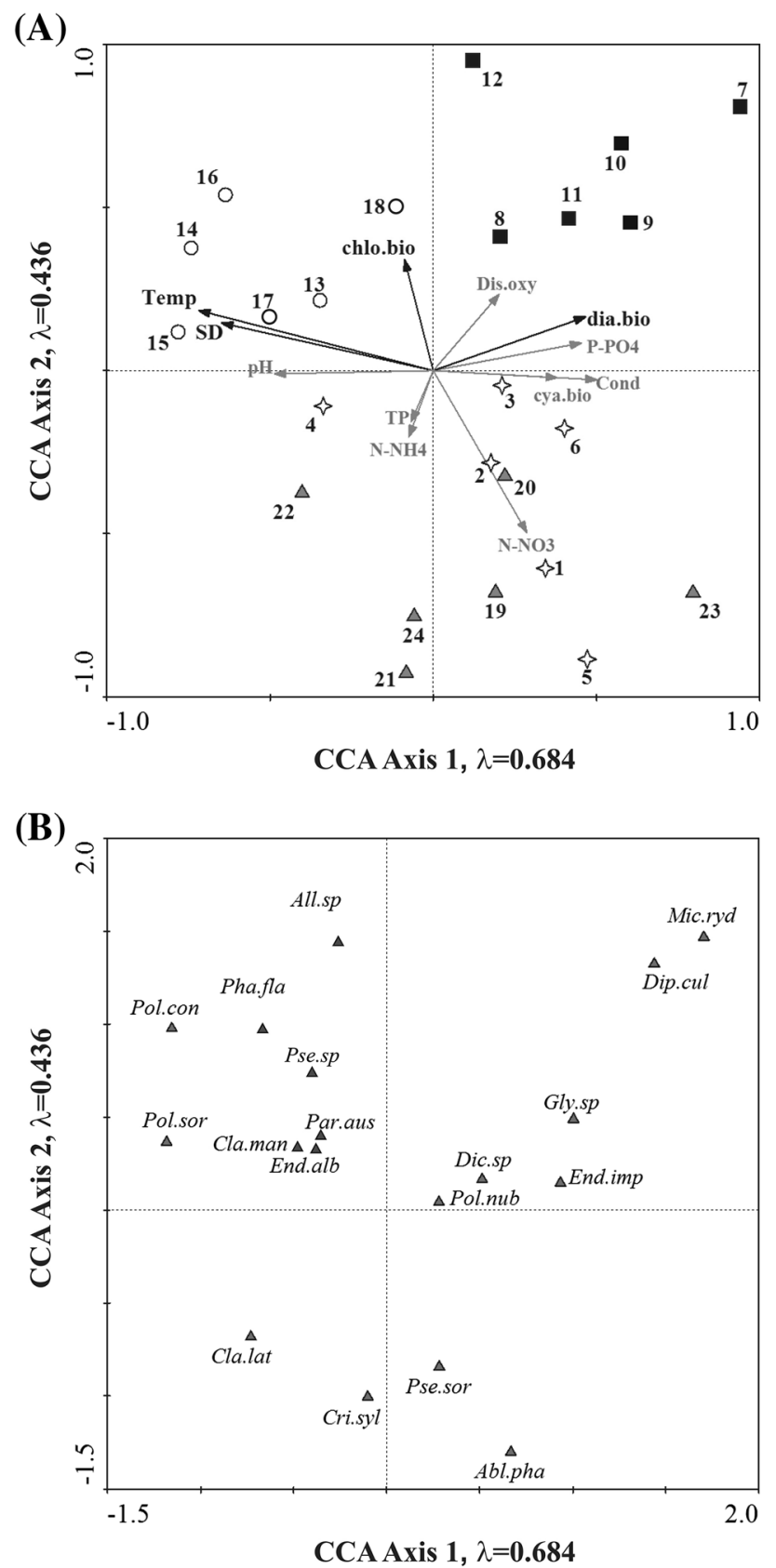

Fig. 4 Canonical correspondence analysis (CCA) scatter plots for axis 1 and 2 showing a samples and environmental variables and b chironomid taxa. Solid arrows indicate significant variables based on Monte Carlo permutation test $(P<0.05)$. SD Secchi disc visibility, Temp temperature, Cond conductivity, Dis.oxy dissolved oxygen, $\mathrm{N}-\mathrm{NH}_{4}$ ammonium nitrogen, $\mathrm{N}-\mathrm{NO}_{3}$ nitrate nitrogen, $\mathrm{TP}$ total phosphorus, $\mathrm{P}-\mathrm{PO}_{4}$ dissolved orthophosphates, chlo.bio biomass of chlorophytes, dia.bio biomass of diatoms; cya.bio biomass of cyanobacteria. Samples collected at macrophyte species are marked with an Arabic numeral 1-6 Ch. aculeolata, 7-12 S. aloides, 13-18 P. lucens, 19-24 M. spicatum. Mean sample scores for each macrophyte species and season are presented to simplify the graph. Taxa codes are the same as on Fig. 3
Table 3 Values of Pearson correlation coefficients between chironomid taxa and periphytic algae on the four studied macrophytes

\begin{tabular}{lllll}
\hline & Ch. & S. & P. lucens & M. \\
& aculeolata & aloides & & spicatum \\
\hline Ablabesmyia phatta & & & $-0.36 \mathrm{~ns}$ \\
Cricotopus sylvestris & & & $\mathbf{0 . 8 3} *$
\end{tabular}

gr.

Diplocladius

$0.89 * *$

cultriger

Psectrocladius sp.

Psectrocladius sordidellus gr.

Allochironomus sp.

Cladopelma lateralis gr.

Dicrotendipes sp. $0.72 \mathrm{~ns} \quad \mathbf{0 . 8 3}^{*} \quad-0.16 \mathrm{~ns}$

Endochironomus $0.64 \mathrm{~ns}$ $-0.54 \mathrm{~ns} \quad-0.51 \mathrm{~ns}$ albipennis gr.

Endochironomus impar

\section{Glyptotendipes sp.}

$0.33 \mathrm{~ns}$

$0.34 \mathrm{~ns}$

$-0.54 \mathrm{~ns} \quad-0.28 \mathrm{~ns}$

Microtendipes rydalensis gr.

Phaenopsectra flavipes

Polypedilum sordens

Polypedilum

convictum gr.

Polypedilum nubeculosum gr.

Cladotanytarsus mancus

$-0.48 \mathrm{~ns} \quad-\mathbf{0 . 6 3}^{* *} \quad-0.26 \mathrm{~ns}$

0.88 *

$\mathbf{0 . 6 2} *-0.63 \mathrm{~ns}$

$0.11 \mathrm{~ns} \quad 0.18 \mathrm{~ns} \quad \mathbf{0 . 8 5}^{*}$

$0.21 \mathrm{~ns}$

$-0.11 \mathrm{~ns} \quad-0.43 \mathrm{~ns} \quad-0.07 \mathrm{~ns}$

$0.19 \mathrm{~ns} \quad 0.72 \mathrm{~ns}$

Paratanytarsus

$0.83 * *$ $-0.14 \mathrm{~ns} \quad-0.12 \mathrm{~ns} \quad-0.27 \mathrm{~ns}$ austriacus

$n=36$, ns $P>0.05, * 0.05<P<0.01$, ** $0.01<P<0.001$ : significant results in bold

important top-regulators of periphytic algal biomass was indicated previously in a shallow, phytoplankton-dominated (turbid water) lake (Tarkowska-Kukuryk 2013). The high proportions of algae in the gut of dominant chironomid taxa suggest that under low nutrient concentrations (a clear-water lake), the availability of food (algae) should be considered as an important determinant of chironomid distribution.

The distribution of chironomids between macrophyte species was affected by environmental factors. CCA analysis separated studied macrophytes and chironomids into three groups. The abundance of chironomid taxa associated with $S$. aloides was closely related to dissolved 
oxygen and $\mathrm{P}-\mathrm{PO}_{4}$. The presence of Stratiotes decreases concentrations of phosphorus; the plant might withdraw nutrients not only from the sediment but also from the surrounding water (Brammer and Wetzel 1984). Precipitation of phosphorus on Stratiotes leaves can be a possible explanation for clear water (high oxygen content) around Stratiotes plants. Temperature (season) and Secchi disc visibility affect the distribution of chironomids on $P$. $l u$ cens. Temperature is regarded as an important abiotic factor regulating the life cycle of chironomids, egg development and emergence of larvae (Gresens 1997). The Secchi disc depth may help to explain the role of light in the production of different parts of the macrophyte; generally, the upper part has greater light availability because of better exposure (Wetzel 2001). Light availability can control vertical distribution of periphyton on leaves of Potamogeton and indirectly affects its colonisation by chironomids. The analysis of algae-chironomid relations on Ch. aculeolata and M. spicatum indicates that these macrophytes create similar, less favourable habitats for periphytic algae and associated chironomids. Charophytes concentrate most of their biomass close to the sediment surface, and at that depth the development of periphytic algae is light limited (van den Berg et al. 1998). Low availability of algae (food) does not create a favourable substrate for chironomids. On M. spicatum, the chironomid structure was specific; larvae of Cricotopus sylvestris gr. were only noted at the site. It has been reported that larvae of the genus Cricotopus are very host-specific to Myriophyllum species (Menzie 1981; Balci and Kennedy 2003). The larvae are able to feed on meristematic tissue, suppressing the plant's growth (McRae et al. 1990). Moreover, CCA analysis showed the relationship between chironomid assemblages on Ch. aculeolata and M. spicatum to the concentrations of $\mathrm{N}-\mathrm{NH}_{4}$ and $\mathrm{N}-\mathrm{NO}_{3}$. The concentration of nitrogen compounds may have a significant effect on the increase in length of Chara spp. (Simons et al. 1994), as well the increase in biomass of M. spicatum (Anderson and Kalff 1986). The algal population (food source) in macrophyte-dominated shallow lakes is often found to be nitrogen limited (Moss et al. 2005).

The habitat (macrophyte species) preferences of larval chironomids in a shallow clear-water lake are related to the biomass of periphytic algae on host plants and to environmental variables (oxygen, nutrients) specific to the macrophyte stand.

Acknowledgments The study was supported by the research grant N N304 339133 "Trophic interactions between macrophytes, periphytic algae and epiphytic invertebrates in shallow lake ecosystems", provided by the Polish National Science Foundation. I would like to thank three anonymous reviewers for many valuable critical comments to the manuscript.
Open Access This article is distributed under the terms of the Creative Commons Attribution License which permits any use, distribution, and reproduction in any medium, provided the original author(s) and the source are credited.

\section{References}

Albay M, Aykulu G (2002) Invertebrate grazer-epiphytic algae interactions on submerged macrophytes in a mesotrophic Turkish lake. E.Ü. Su Ürünleri Dergisi 19:247-258

Anderson MR, Kalff J (1986) Nutrient limitation of Myriophyllum spicatum growth in situ. Freshw Biol 16:735-743

Balci P, Kennedy JH (2003) Comparison of chironomids and other macroinvertebrates associated with Myriophyllum spicatum and Heteranthera dubia. J Freshw Ecol 18:235-247

Bauer N, Blaschke U, Beutler E, Gross EM, Jenett-Siems K, Siems K, Hilt S (2009) Seasonal and interannual dynamics of polyphenols in Myriophyllum verticillatum and their allelopathic activity on Anabaena variabilis. Aquat Bot 91:110-116

Becerra-Munoz S, Schramm HL (2007) On the influence of substrate morphology and surface area on phytofauna. Hydrobiologia 575:117-128

Berg MB (1995) Larval food and feeding behavior. In: Armitage PD, Cranston PS, Pinder LCV (eds) The Chironomidae. Biology and ecology of non-biting midges. Chapman \& Hall, London, pp 136-168

Bernatowicz S (1960) Methods of plant studies in lakes. Rocz Nauk Rol 77:61-79

Blindow I (1987) The composition and density of epiphyton on several species of submerged macrophytes - the neutral substrate hypothesis tested. Aquat Bot 29:157-168

Brammer ES, Wetzel RG (1984) Uptake and release of $\mathrm{K}+$, $\mathrm{Na}+$ and $\mathrm{Ca} 2+$ by the water soldier, Stratiotes aloides $\mathrm{L}$. Aquat Bot 19:119-130

Brönmark C, Klosiewski SP, Roy AS (1992) Indirect effect of predation in a freshwater benthic food chain. Ecology 73:16621674

Brooks SJ, Bennion H, Birks HJB (2001) Tracing lake trophic history with a chironomid-total phosphorus inference model. Freshw Biol 46:513-533

Cañedo-Argüelles M, Rieradevall M (2009) Quantification of environment-driven changes in epiphytic macroinvertebrate communities associated to Phragmites australis. J Limnol 68:229-241

Cattaneo A (1983) Grazing on epiphytes. Limnol Oceanogr 28:124132

Cattaneo A, Galanti G, Gentinetta S, Romo S (1998) Epiphytic algae and macroinvertebrates on submerged and floating-leaved macrophytes in an Italian lake. Freshwater Biol 39:725-740

Cerba D, Mihaljevic Z, Vidakovic J (2010) Colonisation of temporary macrophyte substratum by midges (Chironomidae: Diptera). Ann Limnol Int J Lim 46:181-190

Chernovski AA (1949) Opredelitel lichinok komarov semeistva Tendipedinae. Izv. Akad. Nauk, SSSR

Cheruvelil KS, Soranno PA, Serbin RD (2000) Macroinvertebrates associated with submerged macrophytes: sample size and power to detect effects. Hydrobiologia 441:133-139

Cyr H, Downing JA (1988) Empirical relationships of phytomacrofaunal abundance to plant biomass and macrophyte bed characteristics. Can J Fish Aquat Sci 45:976-984

Dvorak J (1996) An example of relationships between macrophytes, macroinvertebrates and their food resources in a shallow eutrophic lake. Hydrobiologia 339:27-36 
Dvorak J, Best EPH (1982) Macroinvertebrate communities associated with the macrophytes of Lake Vechten: structure and functional relationships. Hydrobiologia 95:115-126

Golterman HL (1969) Methods for chemical analysis of freshwaters. IBP Handbook No. 8. Blackwell Scientific Publications, Oxford

Gresens SE (1997) Interactive effects of diet and thermal regime on growth of the midge Pseudochironomus richardsoni Malloch. Freshw Biol 38:365-373

Gross EM, Feldbaum C, Graf A (2003) Epiphyte biomass and elemental composition on submersed macrophytes in shallow eutrophic lakes. Hydrobiologia 506(509):559-565

Hansen JP, Wikström SA, Axemar H, Kautsky L (2011) Distribution differences and active habitat choices of invertebrates between macrophytes of different morphological complexity. Aquat Ecol 45:11-22

Hermanowicz W, Dojlido J, Dożańska W, Kosiorowski B, Zerbe J (1999) Fizyczno-chemiczne badanie wody i ścieków. Arkady, Warszawa

Hirabayashi K, Wotton RS (1999) Organic matter processing by chironomid larvae (Diptera: Chironomidae). Hydrobiologia 382:151-159

James MR, Hawlest I, Waetherhead M (2000) Removal of settled sediments and periphyton from macrophytes by grazing invertebrates in the littoral zone of a large oligotrophic lake. Freshw Biol 44:311-326

Jones JI, Sayer CD (2003) Does the fish-invertebrate-periphyton cascade precipitate plant loss in shallow lakes? Ecology $84: 2155-2167$

Kahlert M, Pettersson K (2002) The impact of substrate and lake trophy on the biomass and nutrient status of benthic algae. Hydrobiologia 489:161-169

Koperski P (1998) Predator-prey interactions between larval damselflies and mining larvae of Glyptotendipes gripekoveni (Chironomidae): reduction in feeding activity as an induced defence. Freshw Biol 39:317-324

Kornijów R (1986) Fauna living on the plants and mining fauna associated with Potamogeton lucens L. in the eutrophic Lake Głębokie. Ann UMCS Lublin 41:127-133

Kornijów R (1998) Quantitative sampler for collecting invertebrates associated with submersed and floating-leaved macrophytes. Aquat Ecol 32:241-244

Lalonde S, Downing JA (1991) Epiphyton biomass is related to lake trophic status, depth and macrophyte architecture. Can J Fish Aquat Sci 48:2285-2291

Laugaste R, Reunanen R (2005) The composition and density of epiphyton on some macrophyte species in the partly meromictic Lake Verevi. Hydrobiologia 547:137-150

Lawrence JM, Gresens SE (2004) Foodweb response to nutrient enrichment in rural and urban streams. J Freshw Ecol 19:375-385

Lepš J, Šmilauer P (2003) Multivariate analysis of ecological data using CANOCO. Cambridge University Press, Cambridge

Liboriussen L, Jeppesen E, Bramm ME, Lassen MF (2005) Periphyton-macroinvertebrate interactions in light and fish manipulated enclosures in a clear and a turbid shallow lake. Aquat Ecol 39:23-39

Lindegaard C (1995) Classification of water bodies and pollution. In: Armitage PD, Cranston PS, Pinder LCV (eds) The Chironomidae. Biology and ecology of non-biting midges. Chapman \& Hall, London, pp 384-404

Lods-Crozet B, Lachavanne JB (1994) Changes in chironomid communities in Lake Geneva in relation with eutrophication, over a period of 60 years. Arch Hydrobiol 130:453-471

Loeb S, Reuter JE (1981) The epilithic periphyton community: a five lake comparative study of community productivity, nitrogen metabolism and depth distribution of standing crop. Verh Inter Verein Limnol 21:346-352

Maasri A, Fayolle S, Franquet E (2010) Algal foraging by a rheophilic chironomid (Eukiefferiella claripennis Lundbeck) extensively encountered in high nutrient enriched streams. Fund Appl Limnol 177:151-159

McCollum EW, Crowder LB, McCollum SA (1988) Complex interactions of fish, snails and littoral zone periphyton. Ecology 79:1980-1994

McRae IV, Winchester NN, Ring RA (1990) Feeding activity and host preference of the milfoil midge, Cricotopus myriophylli Oliver, (Diptera: Chironomidae). J Aquat Plant Manage 28:89-92

Menzie CA (1981) Production ecology of Cricotopus sylvestris (Fabricius) (Diptera: Chironomidae) in a shallow estuarine cove. Limnol Oceanogr 26:467-481

Meulemans JT, Roos PJ (1985) Structure and architecture of periphytic community on dead reed stems in lake Maarsseveen. Arch Hydrobiol 102:487-502

Moeller RE, Burkholder JM, Wetzel RG (1988) Significance of sedimentary phosphorus to rooted submerged macrophytes (Najas flexilis (Willd.) Rostk. and Schmidt) and its algal epiphytes. Aquat Bot 32:261-281

Moss B, Barker T, Stephen D, Williams AE, Balayla DJ, Beklioglu M, Carvalho L (2005) Consequences of reduced nutrient loading on a lake system in a lowland catchment: deviations from the norm? Freshw Biol 50:1687-1705

Mulderij G, van Nes EH, van Donk E (2007) Macrophytephytoplankton interactions: the relative importance of allelopathy versus other factors. Ecol Model 204:85-92

Noges T, Luup H, Feldmann T (2010) Primary production of aquatic macrophytes and their epiphytes in two shallow lakes (Peipsi and Vortajärv) in Estonia. Aquat Ecol 44:83-92

Peets R, Miller AC, Beckett DC (1994) Effects of three species of aquatic plants on macroinvertebrates in Lake Seminole, Georgia. U.S. Army Corps of Engineers Waterway Experiment Station, Technical Report A-94-5, Vicksburg

Pinder LCV (1986) Biology of freshwater Chironomidae. Ann Rev Ent 31:1-23

Pinder LCV (1992) Biology of epiphytic Chironomidae (Diptera: Nematocera) in a chalk stream. Hydrobiologia 248:39-51

Pip E, Robinson GGC (1984) A comparison of algal periphyton composition on eleven species of submerged macrophytes. Hydrobiol Bull 18:109-118

Rantala MJ, Ilmonen J, Koskimäki J, Suhonen J, Tynkkynen K (2004) The macrophyte, Stratiotes aloides, protects larvae of dragonfly Aeshna viridis against fish predation. Aquat Ecol 38:77-82

Romo S, Galanti G (1998) Vertical and seasonal distribution of epiphytic algae on water chestnut (Trapa natans). Arch Hydrobiol 141:483-504

Rott E (1981) Some results from phytoplankton counting intercalibrations. J Hydrol 43:34-62

Simons J, Ohm M, Daalder R, Boers P, Rip W (1994) Restoration of Botshol (the Netherlands) by reduction of external nutrient load: recovery of characean community dominated by Chara connivens. Hydrobiologia 275(276):243-253

Tall L, Cattaneo A, Cloutier L, Dray S, Legendre P (2006) Resource partitioning in a grazer guild feeding on a multilayer diatom mat. J N Am Benthol Soc 25:800-810

Taniguchi H, Nakano S, Tokeshi M (2003) Influences of habitat complexity on the diversity and abundance of epiphytic invertebrates on plants. Freshwater Biol 48:718-728

Tarkowska-Kukuryk M (2006) Water soldier Stratiotes aloides L. (Hydrochariceae) as a substratum for macroinvertebrates in a shallow eutrophic lake. Pol J Ecol 54:441-451 
Tarkowska-Kukuryk M (2011) Composition and distribution of epiphytic midges (Diptera: Chironomidae) in relation to emergent macrophyte cover in shallow lakes. Pol J Ecol 59:141-151

Tarkowska-Kukuryk M (2013) Periphytic algae as food source for grazing chironomids in a shallow phytoplankton dominated lake. Limnologica 43:254-264

ter Braak CJF, Šmilauer P (2002) CANOCO reference manual and user's guide to CANOCO for Windows: software for canonical community ordination (version 4.5). Microcomputer Power, Ithaca

Tessier C, Cattaneo A, Pinel-Alloul B, Galanti G, Morabito G (2004) Biomass, composition and size structure of invertebrate communities associated to different types of aquatic vegetation during summer in Lago di Candia (Italy). J Limnol 63:190-198

Toporowska M, Pawlik-Skowrońska B, Krupa D, Kornijów R (2010) Winter versus summer blooming of phytoplankton in a shallow lake: effect of hypertrophic conditions. Pol J Ecol 58:3-12

van de Meutter F, Cottenie K, de Meester L (2008) Exploring differences in macroinvertebrate communities from emergent, floating-leaved and submersed vegetation in shallow ponds. Fund Appl Limnol 173:47-57

van den Berg MS, Scheffer M, Coops H (1998) The role of characean algae in the management of eutrophic shallow lakes. J Phycol 34:750-756 van den Hoek C, Mann DG, Jahns HM (1995) An introduction to phycology. Cambridge University Press, Cambridge

Vermaat JE (2005) Periphyton dynamics and influencing factors. In: Azim ME, Verdegem MCJ, van Dam AA, Beveridge MCM (eds) Periphyton. Ecology, exploitation and management. CABI Publishing, London, UK, pp 35-49

Vermaat JE, Hootsmans MJM (1994) Periphyton dynamics in a temperature-light gradient. In: van Vierssen W, Hootsmans MJM, Vermaat JE (eds) Lake Veluwe, a macrophyte-dominated system under eutrophication stress. Geobotany 21. Kluwer, The Netherlands, pp 193-212

Warfe DM, Barmuta LA (2004) Habitat structural complexity mediates the foraging success of multiple predator species. Oecologia 14:171-178

Wetzel RG (2001) Limnology, 3rd edn. Academic Press Elsevier, San Diego

Wiederholm T (1983) Chironomidae of the Holarctic region. Keys and diagnoses. Part 1. Larvae. Entomologica Scandinavica. Supplement 19. Borgströms Tryckeri AB, Motala 